\title{
Cinnamomum mabberleyi, a new species from Vietnam and Laos
}

\author{
R.P.J. de Kok \\ Honorary Research Associate \\ Singapore Botanic Gardens, National Parks Board, \\ 1 Cluny Road, 259569 Singapore \\ rogier.dekok@yahoo.com
}

\begin{abstract}
A new species of Cinnamomum (Lauraceae), C. mabberleyi, is named from Vietnam and Laos. A formal description, notes on distribution, conservation status and ecology, and a map are given; it is differentiated from Cinnamomum tsoi C.K.Allen.
\end{abstract}

Keywords. Cinnamomum, Laos, Vietnam

\section{Introduction}

The genus Cinnamomum Schaeff. was first described in 1760 based on a widelycultivated species (Schäffer, 1760), which was then called Laurus cinnamomum L., but is now known as Cinnamomum verum J.Presl. It comprises about 300 species and occurs naturally in tropical and subtropical Asia, Australia and the Pacific (van der Werff, 2001: 135). The South American species have now been moved to Aiouea Aubl. (Rohde et al., 2017). The bark, flowers and fruits of a small number of species are used as spices, and these species are now commonly cultivated throughout the tropics, while other species are used as shade trees and often locally as medicine for several ailments (Kostermans, 1986).

The brothers Christian \& Theodor Nees von Esenbeck (1823) wrote a book on the then known species, and one of them (Christian) later revised the taxonomy in his Systema Laurinarum (Nees von Esenbeck, 1836). The genus was also studied by several authors in the $20^{\text {th }}$ century: for Indonesia by Cammerloher (1925), and for South China and Indochina by both Liou Ho (1932) and Allen (1939). More recent works on the genus in the region include revisions of the species for Borneo (Soh, 2011), China (Li et al., 2008) and Peninsular Malaysia (de Kok, 2019). In addition, Kostermans planned to revise all the Asian species in a set of five papers but only three of these were published, one dealing with the species of the Eastern Malaysian islands (Kostermans, 1986), another with the species from South India (Kostermans, 1985) and one as part of the flora of Sri Lanka (Kostermans, 1983). The two remaining papers were prepared but never published, one dealing with the species in western Malesia and the other with the species in China. Copies of these unpublished papers are now kept at the Botanical Library of the Naturalis Biodiversity Center in Leiden, The Netherlands. A third unpublished manuscript exists of a revision of the Lauraceae 
of Thailand, which was written while he was in Aarhus, Denmark, which included 13 species of Cinnamomum. In his preparation of these revisions, Kostermans visited many herbaria (including BKF, BM, K, L, P and SING) and named many specimens, sometimes with names that he had not yet published. For many of these names I could not find any evidence that they were ever published - something which is common with that author in several groups (see de Kok, 2015, 2016). Some of these non-validated names have over the years been used in Floras and Checklists (Hô, 1991; Lê, 2003).

One of these taxa is currently known as Cinnamomum crispulum Kosterm. which was never validly published but is listed in the Illustrated Flora of Vietnam (Hô, 1991: 347) and in the Vietnam Checklist (Lê, 2003), neither instance constituting valid publication. Another name is Cinnamomum microphilis Kosterm. which is also unpublished, and this name was never taken up in any subsequent publications. It was first described as a variety (var. dentricupullatum) of Cinnamomum litseaefolium Thwaites by Liou Ho (1932: 36).

During my work on the Flora of Laos, Cambodia and Vietnam, I discovered that these two invalid names (Cinnamomum crispulum and C. microphilis) are attributed to what is one species. Liou Ho (1932) also named some of the specimens of this species as Cinnamomum tamala (Buch.-Ham.) T.Nees \& C.H.Eberm. and Cinnamomum soncaurium (Buch.-Ham.) T.Nees \& C.H.Eberm, which are clearly wrong identifications. I would like to name this new species in honour of Prof. David Mabberley, who was my D.Phil. supervisor at Oxford University, and, as Keeper of the Herbarium, Library, Arts and Archives department of the Royal Botanic Gardens at Kew, he encouraged me to begin working on the Lauraceae.

\section{Cinnamomum mabberleyi de Kok, sp. nov.}

This species differs from Cinnamomum tsoi C.K.Allen in having curly hairs on the twigs (straight in C.tsoi); in having leaves that are alternate (opposite in C. tsoi) with an acute to acuminate apex (rounded in $C$. tsoi) and a lower leaf surface that is sparsely hairy (glabrous in C. tsoi) and when in fruit with a perianth cup with slightly lobed margins (margin entire in C. tsoi). - TYPE: [Vietnam] Haut Donnaï, Blao, 2 February 1933, E. Poilane 21803 (holotype P [P01748429]). (Fig. 1)

Cinnamomum litseaefolium Thwaites var. dentricupullatum H.Liou, Laurac. Chine \& Indo-Chine 36 (1932). - TYPE: [Vietnam] Prov. du Haut Donnaï, Blao, 1 March 1933, E. Poilane 22187 (lectotype P [P02132181] designated here, isolectotype L [L0035761]).

Cinnamomum tamala auct. non (Buch.-Ham.) T.Nees \& C.H.Eberm: Liou Ho, Laurac. Chine \& Indo-Chine 34 (1932); P.H.Hô, Ill. Fl. Vietnam 349 (1991); C.Lê, Checklist P1. Sp. Vietnam 81 (2003); Newman et al., Checkl. Vasc. Pl. Laos 173 (2007).

Cinnamomum soncaurium auct. non (Buch.-Ham.) T.Nees \& C.H.Eberm.: P.H.Hô, Ill. F1. Vietnam 349 (1991). 


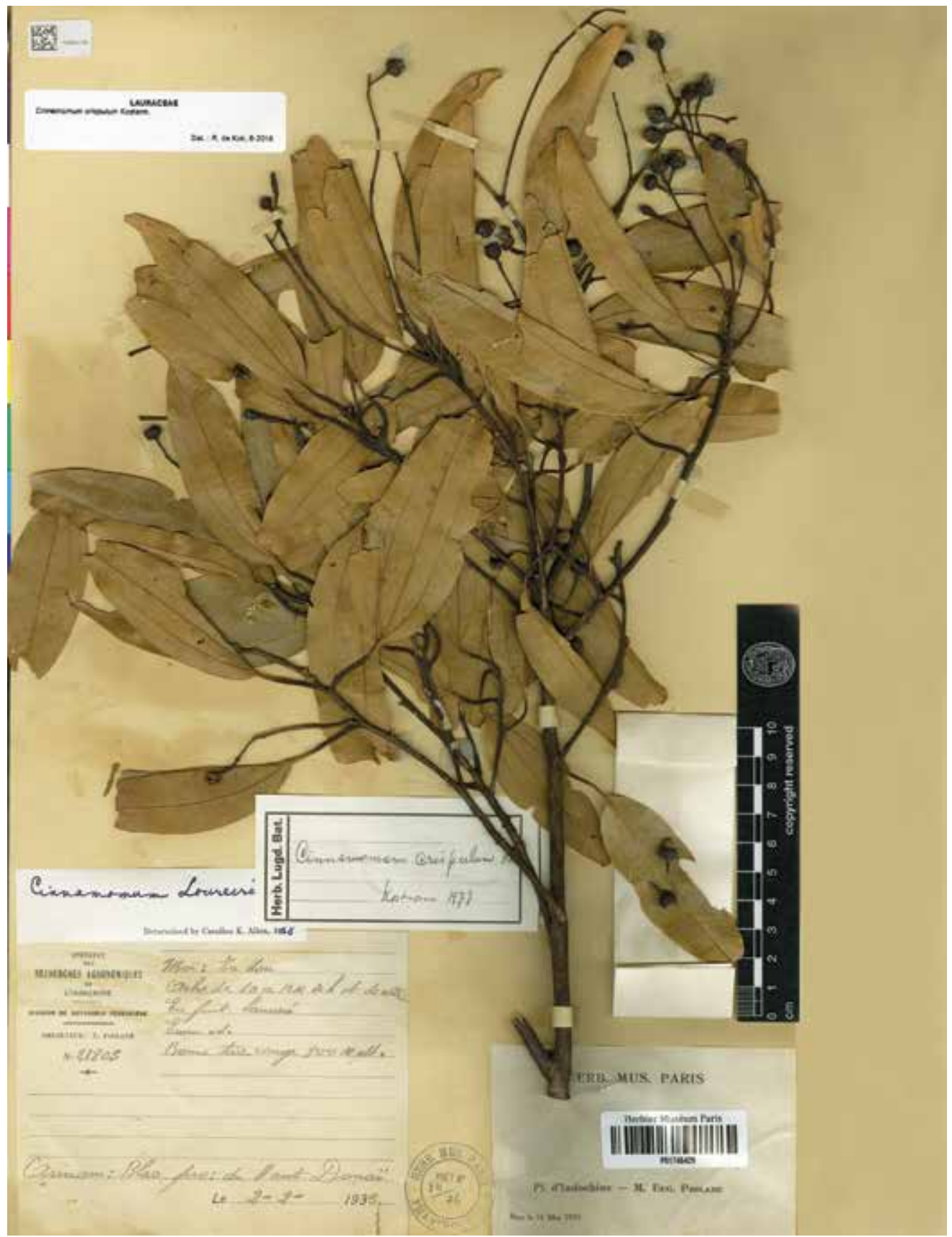

Fig. 1. Photograph of the holotype of Cinnamomum mabberleyi de Kok, held at the Muséum National d'Histoire Naturelle in Paris 
[Cinnamomum crispulum Kosterm., ined.; P.H.Hô, Ill. Fl. Vietnam 347 (1991); C.Lê, Checklist Pl. Sp. Vietnam 76 (2003).]

Trees, 6-22 m tall, dbh 10-30 cm. Twigs slender, 2-4.5 mm thick, rounded in crosssection, densely hairy when young, soon glabrescent; hairs yellowish, curly; terminal leaf bud ovoid or lanceolate, 4-6 mm long, apex acute, velutinous. Leaves alternate, domatia absent; leaf blade ovate-elliptic, 7-13 $\times 3-6.4 \mathrm{~cm}$, apex acute to acuminate, base rounded to cuneate, leathery, triplinerved, secondary nerves one pair, tertiary nerves scalariform-reticulate; upper surface glabrous, midrib raised to flattened, secondary nerves raised, tertiary nerves indistinct; lower surface sparsely hairy, midrib and secondary nerves raised, tertiary nerves indistinct; petiole half-terete, $9.5-11 \mathrm{~mm}$, slender, glabrous. Inflorescence a many-flowered panicle, axillary, 9-13 cm long, densely to sparsely hairy, denser on nodes; bracteoles lanceolate, c. $3 \mathrm{~mm}$ long, apex acute, caducous. Flowers with perianth tube shallow; perianth lobes ellipsoid, 2.5-3 $\times 1.5-1.9 \mathrm{~mm}$, apex acute, densely hairy outside; stamens $2.9-3.2 \mathrm{~mm}$ long, hairy, anthers 4-celled; ovary ellipsoid, c. 2 mm diameter, glabrous. Fruit ellipsoid, 6-12 $\times$ 4-6 mm, apex rounded, glabrous, hairy at apex; perianth cup shallow, 6-10 mm diameter, margin slightly lobed; lobes 1.3-1.6 mm long, apex rounded; stalk slender to slightly tapering up to $1.5 \mathrm{~mm}$ diameter.

Distribution. Vietnam and Laos.

Ecology. Growing in wet forest at 400-1600 m altitude. Flowering in May; fruiting in December to March.

Additional specimens examined. VIETNAM. Quảng Trị: Col d'Quilas, 6 Jan 1932, Poilane 19920 (P). Binh Hòa: Station experimental de Giaraï, 1918, Poilane 39653 (P). Haut Donnaï: Blao, 24 Sep 1932, Poilane 20959 (P); Blao, 2 Feb 1933, Poilane 21803 (P). Kon Tum: Daklo, 19 Dec 1946, Poilane 35523 (P). Nhatrang: $25 \mathrm{~km}$ route de Nhatrang, 20 Oct 1923, Poilane 8344 (K, P). Bình Phước: Bu-dop, prope Chudaumol, 29 Nov 1919, Poilane 845 (K, P).

LAOS. Attopeu: 8 August 1877, Harmand 1367 (K, P). Savannakhet: 21 Jan 1925, Poilane 11732 (K); 19 Jan 1925, Poilane 11656 (K, P); 28 Jan 1925, Poilane 11814 (BM, P); 6 Feb 1925, Poilane 11900 (BM, P); près Savannakhet, 3 Mar 1925, Poilane 12080 (P). Phongsaly: Phong Saly, 5 May 1936, Poilane 25978 (P). Champasak: Kil, 20 de la route de Pakse, 20 Nov 1938, Poilane 28504 (P).

ACKNOWLEDGEMENTS. The author is grateful to the curators of the herbaria at BM, K, and $\mathrm{P}$ for access to the specimens used in the present study. I would in particular like to thank the Muséum National d'Histoire Naturelle Paris for providing and given permission to publish the picture of the type specimen. This research received support from the SYNTHESYS Project (http://www.synthesys.info/), which is financed by the European Union Research Infrastructure Action under the FP7 "Capacities Program". Finally, I thank David Mabberley for helping me start my botanical career and for giving me the space to develop my own research and ideas. 


\section{References}

Allen, C.K. (1939). Studies in the Lauraceae. II some critical and new species of Cinnamomum and Neocinnamomum. J. Arnold Arbor. 20: 44-63.

Cammerloher, H. (1925). Die Cinnamomum-Arten von Niederländisch-Ostindien. Bull. Jard. Bot. Buitenzorg, ser. III, 7: 446-497.

de Kok, R.P.J. (2015). A revision of Cryptocarya (Lauraceae) of Thailand and Indo-China. Gard. Bull. Singapore 67: 309-350.

de Kok, R.P.J. (2016). A revision of Beilschmiedia (Lauraceae) of Peninsular Malaysia. Blumea 61: 147-164.

de Kok, R.P.J. (2019). A revision of Cinnamomum Schaeff. (Lauraceae) for Peninsular Malaysia and Singapore. Gard. Bull. Singapore 71 (1): 89-139.

Hô, P.H. (1991). Illustrated Flora of Vietnam, $3^{\text {rd }}$ ed., vol. 1. Montreal: Pham Hoang Ho.

Kostermans, A.J.G.H. (1983). Lauraceae. In: Dassanayake, M.D. (ed.) A revised handbook to the flora of Ceylon, vol. 9, pp. 105-172. Rotterdam: Balkema.

Kostermans, A.J.G.H. (1985). The South Indian species of Cinnamomum Schaeffer(Lauraceae). Bull. Bot. Surv. India 25: 90-133.

Kostermans, A.J.G.H. (1986). A monograph of the genus Cinnamomum Schaeffer (Lauraceae) Part I. Ginkgoana 6: 1-171.

Lê, T.C. (2003). Danh luc các loài thục vật Việt Nam (= Checklist of plant species of Vietnam) Hà Nội: Nhà Xuất Bản Nông Nghiệp.

Liou Ho (1932). Contribution à l'Étude systématique et phytogéographique des Lauracées de Chine et d'Indochine. Paris: Jouve \& Co.

Li, X., Li, J., Huang, P., Wei, F., Cui, H., \& van der Werff, H. (2008). Lauraceae. In: Wu, Z.Y. \& Raven, P. (eds) Flora of China, vol. 7, pp. 102-254. Beijing: Science Press.

Nees von Esenbeck, C.G.D. \& Nees von Esenbeck, T.F.L. (1823). De cinnamomo disputatio. Bonnae.

Nees von Esenbeck, C.G.D. (1836). Systema laurinarum. Berolini: Sumptibus Veitii et Sociorum.

Rohde, R., Rudolph, B., Ruthe, K., Lorea-Hernández, F.G., de Moraes, P.L.R., Li, J. \& Rohwer, J.G. (2017). Neither Phoebe nor Cinnamomum - the tetrasporangiate species of Aiouea (Lauraceae). Taxon 66: 1085-1111.

Schäffer, J.C. von (1760). Botanica expeditior, genera plantarum in tabulis sexualibus et universalibus aeri incises exhibens. Ratisbonae: Litteris Fratr. Zunkel.

Soh, W.K. (2011). Taxonomic revision of Cinnamomum (Lauraceae) in Borneo. Blumea 56: 241-264.

van der Werff, H. (2001). An annotated key to the genera of Lauraceae in the Flora Malesiana Region. Blumea 46: 125-140. 
